Request for an Opinion

\author{
Correspondence \\ David R. Arahal \\ arahal@uv.es
}

\section{The status of the species Pectinatus portalensis Gonzalez et al. 2005. Request for an Opinion}

\author{
Claudine Vereecke ${ }^{1}$ and David R. Arahal ${ }^{2}$ \\ ${ }^{1}$ BCCM/LMG Bacteria Collection, Ghent University, K. L. Ledeganckstraat 35, B-9000 Gent, \\ Belgium \\ ${ }^{2}$ Colección Española de Cultivos Tipo (CECT) and Departamento de Microbiología y Ecología, \\ Universitat de València, Campus de Burjassot, 46100 València, Spain
}

\begin{abstract}
On the basis of 16S rRNA gene sequence analysis and several key phenotypic features, it was ascertained that the cultures cited as the type strain of the species Pectinatus portalensis, CECT $5841^{\top}$ and LMG $22865^{\top}$, do not conform to the description, [Gonzalez, J. M., Jurado, V.,

Laiz, L., Zimmerman, J., Hermosin, B. \& Saiz-Jimenez, C. (2004). Antonie van Leeuwenhoek 86, 241-248]. The type strain does not exist in any other established culture collection or with the authors who described this species. Therefore, it cannot be included in any scientific study. It is proposed that the Judicial Commission place the name Pectinatus portalensis on the list of rejected names if a suitable replacement type strain is not found or a neotype is not proposed within two years following the publication of this Request for an Opinion.
\end{abstract}

The species Pectinatus portalensis was described by Gonzalez et al. (2004) based on a single strain, B6, as an obligate anaerobic, Gram-negative bacterium possessing coccoid to slightly oval-shaped cells. The GenBank/EMBL/ DDBJ accession number for the $16 \mathrm{~S}$ rRNA gene sequence of strain $\mathrm{B}^{\mathrm{T}}$ is $\mathrm{AY} 428574$. In the protologue of the effective publication, one culture collection number was given for the type strain, CECT $5841^{\mathrm{T}}$, and later a second one, LMG $22865^{\mathrm{T}}$, was provided on request for validation (Gonzalez et al., 2005). It was later found that none of the deposited strains conformed to the description of the type strain of Pectinatus portalensis.

Based on the results of 16S rRNA gene sequence analysis, strains CECT 5841 and LMG 22865 were identified as Enterococcus faecalis. Indeed they could be cultured aerobically, had a perfect coccal morphology rather than coccoid or oval, and were Gram-positive. These results were obtained separately at the LMG and CECT almost simultaneously and communicated to each party and to the depositor and corresponding author of the original description (Gonzalez et al., 2004). Unfortunately, all attempts to replace the type strain have been unfruitful (Juan M. Gonzalez, personal communication).
According to Rule $18 \mathrm{c}$ of the International Code of Nomenclature of Bacteria (Lapage et al., 1992), if a suitable replacement type strain or a neotype cannot be found or proposed, respectively, within two years of the publication of this Request for an Opinion, it is proposed that the Judicial Commission places the name Pectinatus portalensis on the list of rejected names.

\section{References}

Gonzalez, J. M., Jurado, V., Laiz, L., Zimmermann, J., Hermosin, B. \& Saiz-Jimenez, C. (2004). Pectinatus portalensis nov. sp., a relatively fast-growing, coccoidal, novel Pectinatus species isolated from a wastewater treatment plant. Antonie van Leeuwenhoek 86, 241-248.

Gonzalez, J. M., Jurado, V., Laiz, L., Zimmermann, J., Hermosin, B. \& Saiz-Jimenez, C. (2005). Pectinatus portalensis sp. nov. In Validation of Publication of New Names and New Combinations Previously Effectively Published Outside the IJSEM, List no. 102. Int J Syst Evol Microbiol 55, 547-549.

Lapage, S. P., Sneath, P. H. A., Lessel, E. F., Skerman, V. B. D., Seeliger, H. P. R. \& Clark, W. A. (editors) (1992). International Code of Nomenclature of Bacteria (1990 Revision). Bacteriological Code. Washington, DC: American Society for Microbiology. 